\title{
The Use of HE-4 in Gynecological Cancers
}

\author{
Sinem Ayse Duru Coteli ${ }^{1 *}$, Zeliha Gunnur Dikmen ${ }^{2}$ and Zafer Selcuk Tuncer ${ }^{1}$ \\ ${ }^{1}$ Hacettepe University Faculty of Medicine, Department of Obstetrics and Gynecology \\ ${ }^{2}$ Hacettepe University Faculty of Medicine, Department of Biochemistry
}

Submission: April 29, 2018; Published: May 22, 2018

"Corresponding author: Sinem Ayse Duru Coteli, Hacettepe University Faculty of Medicine, Department of Obstetrics and Gynecology, Sihhiye, Ankara, Turkey, Email: sinemduru@gmail.com

\begin{abstract}
Diagnosing cancer at an early stage and also distinguishing malignancy from benign disease are important areas of medical research. Using tumor biomarkers is a noninvasive procedure for this purpose. HE-4 is a novel biomarker that can be used in gynecologic oncology for early diagnosis, determination of prognosis and follow up. The use of HE-4 in ovarian and endometrial cancers is summarized in this review.

Keywords: HE-4; Ovarian carcinoma; Endometrial carcinoma
\end{abstract}

\section{Introduction}

Human epididymis protein 4 (HE-4) is a whey acidic protein which consists of four disulfide bonds and the gene is located on the short arm of the 20th chromosome [1-3]. It was first discovered on the surface of the epididymal epithelium and has been shown in many other tissues including female reproductive tract $[2,4]$. In 2006, it was shown that the serum levels of HE-4 was elevated in ovarian, edometrial, lung and breast adenocarcinomas [2]. HE4 is also approved as a biomarker by Food and Drug Administration (FDA) for monitoring ovarian cancer (OC) $[1,3]$. The recommended upper limit for HE4 is $150 \mathrm{pmol} / \mathrm{L}$ for premenopausal and postmenopausal women [1]. The main limitation of this cut-off value is that the level of serum HE-4 can differ with increasing age and also HE-4 is cleared through glomerular filtration so the reduced renal functions may alter the results $[1,5,6]$. Also menstrual cycle fluctuations have been shown with HE-4, in follicular phase the values are reported to be lower [7]. In this review we aimed to briefly summarize the use of biomarker HE-4 in gynecological cancers.

\section{HE-4 and Ovarian Cancer}

OC is the leading death from gynecological cancers in developed countries and more than 200.000 new cases are diagnosed world wide annualy $[3,8]$. Since most of the patients are diagnosed at an advanced stage, $\mathrm{OC}$ remains the most lethal gynecologic malignancy. Because of the poor rate of survival, new techniques are needed to detect and screen OC. Novel biomarkers are studied for this purpose. Cancer antigen 125 (CA-125) has been used for screening and for the follow up of patients diagnosed with OC $[1,9]$. It is the most widely used biomarker in gynecology. However, CA-125 has some limitations in clinical use. The marker can be elevated in some benign gynecological conditions and non gynecological conditions, such as endometriosis, infections, pelvic inflammatory disease, pregnancy, other malignancies and conditions with peritoneal, pleural and pericardial inflamation [1,6,9]. Because of these limitations and the low specificity, new biomarkers have been used for detecting early stages of OC. HE-4 was found to increase the sensitivity and specifity for the detection of OC [10-12]. Also HE-4 was found to be overexpressed in clear cell, endometrioid and serous epithelial ovarian carcinomas [1,13].

As HE-4 is not found to be elavated in other medical conditions like CA-125, it can be used as a marker in the diagnosis of OC. In 2009, Moore et al. used an algorithm combining CA-125, HE- 4 and the menopausal status of the patients, which is called the Risk of Malignancy Algorithm (ROMA). With this algorithm $94 \%$ of the patients diagnosed with epithelial ovarian cancer were classified as high risk [14]. There have been many articles published since than with HE-4 in detecting OC. In meta-analysis researchers concluded that the sensitivity and specificity of preoperative HE-4 concentration was greater than CA-125, in detecting OC $[11,15]$.

HE-4 has also been studied in OC for its prognostic value. High levels of HE-4 was correlated with poor prognosis in OC with poor progression free survival $[3,15]$. In a recent metaanalysis, high levels of HE-4 was associated with advanced stage and serous subtypes. HE-4 was not significantly elevated in lymph node metastasis and high grades [15]. 
High levels of HE-4 was also associated with frequent recurence in OC [16]. HE4 is a new target for chemotherapy response in $\mathrm{OC}$ and has role in optimal cytoreduction. If HE-4 levels are measured before first-line chemotherapy in epithelial ovarian carcinoma patients, it can predict the theraphy response $[17,18]$. It is also suggested that cutt off values for optimal cytoreduction should be calculated, then HE-4 can be used as a surgical outcome predictor [19]. However, the cut off values for HE-4 in the diagnosis and prognosis of OC is still conflicting. More studies are needed for modification of cut off values for premenopausal and postmenopausal women to increase the sensitivity and specifity.

\section{HE-4 in Endometrial Cancer}

Endometrial cancer (EC) is the most common gynecological malignancy in developed countries, its insidance is 14.7 and its mortality rate is 2.3 per 100.000 population [20]. Most of the patients are recognised in an early stage and the cure rate is almost $95 \%$ in early stage cancers [21]. It is important to diagnose cancers at an early stage for improving prognosis. Tumor markers have been used for this purpose. CA-125 has also been used in EC to stratify the risk groups and to individualize therapy. However, there are conflicts in this area of research. Although high levels of CA-125 was found to be an independent risk factor for poor prognosis, some researches observed no correlation between CA-125 levels and the stage of the disease [22]. Also the sensitivity and the specificity of CA-125 is lower for EC than OC [21]. Several studies have shown that HE4 is a novel sensitive and specific biomarker for EC [23-25].

HE-4 is found to be indicator of poor prognostic factors including deep myometrial invasion and tumor size in EC [25-27]. Deep myometrial invasion has been accepted as a risk factor for lymph node metastasis [28]. Such high risk patients are staged surgically with hysterectomy, bilateral salpigooferectomy and lymphadenectomy. EC is mostly seen in postmenopausal patients with an avarage age of 60 , however $8 \%$ of EC is seen in patients with younger than age 45 [29]. The main problem of young age in gynecological cancers is the desire for future fertility. As HE-4 is found to be an indicator for myometrial invasion which shows poor prognosis, it can be used to evaluate patients who desire to retain their fertility. On the other hand, HE-4 can be used to avoid over treatment in patients with early stage diseases $[27,30]$.

HE-4 has also been used for determining prognosis and recurrence in EC. Elevated HE-4 level is an independent factor for poor prognosis and overall survival. Besides it is shown that HE-4 can detect recurrence during follow up [31,32]. HE4 levels before treatment for detecting EC is found to be in the range of $50-70 \mathrm{pmol} / \mathrm{L}$ (78,8\% sensitivity and $100 \%$ specificity) in a meta analysis [33].

\section{Conclusion}

HE-4 is a novel biomarker which can be used both in OC and EC for early diagnosis, determination of prognosis and follow up.
Its sensitivity and specificity is promising in these gynecological cancers, hence there is still lack in defining the cut off values, more research is needed in this area.

\section{References}

1. Moore RG, Miller MC, Eklund EE, Lu KH, Bast RC, et al. (2012) Serum levels of the ovarian cancer biomarker HE4 are decreased in pregnancy and increase with age. Am J Obstet Gynecol 206(4): 349.e1-7.

2. Galgano MT, Hampton GM, Frierson HF (2006) Comprehensive analysis of HE-4 expression in normal and malignant human tissues. Modern Pathology 19(6): 847-853.

3. Yuan C, Li R, Yan S, Kong B (2018) Prognostic value of HE4 in patients with ovarian Cancer. Clin Chem Lab Med.

4. Lia L, Zhub Y, Zhongc Y, Suc T, Fand X, et al. (2018) Human epididymis protein 4 in endometrial cancer: A meta-analysis. Clinica Chimica Acta 482: 215-223.

5. Chovanec J, Selingerova I, Greplova K, Antonsen SL, Nalezinska M, et al. (2017) Adjustment of serum HE4 to reduced glomerular filtration and its use in biomarker-based prediction of deep myometrial invasion in endometrial cancer. Oncotarget 8(64): 108213-108222.

6. Nagy B, Krasznai TZ, Balla H, Csoba'n M, Antal-Szalma's P, et al. (2012) Elevated human epididymis protein 4 concentrations in chronic kidney disease. Ann Clin Biochem 49(pt 4): 377-380.

7. Anastasi E, Granato T, Marchei GG, Viggiani V, Colaprisca B, et al. (2010) Ovarian tumor marker HE4 is differently expressed during the phases of the menstrual cycle in healthy young women. Tumor Biol 31(5): 411-415.

8. Hasanbegovic L, Sljivo N (2018) Determination of the Reference Values of the Tumor Marker HE4 in Female Population of Canton Sarajevo. Mater Sociomed 30(1): 15-19.

9. Moore RG, Maclaughlan S, Bast RC (2009) Current state of biomarker development for clinical application in epithelial ovarian cancer. Gynecol Oncol 116(2): 240-245.

10. Moore RG, Brown AK, Miller MC, Skates S, Allard WJ, et al. (2007) The use of multiple novel tumor biomarkers for the detection of ovarian carcinoma in patients with a pelvic mass. Gynecol Oncol (108): 402408.

11. Yang Z, Wei C, Luo Z, Li L (2013) Clinical value of serum human epididymis protein 4 assay in the diagnosis of ovarian cancer: a metaanalysis. Onco Targets and Therapy 6: 957-966.

12. Dikmen ZG, Colak A, Dogan P, Tuncer S, Akbiyik F, et al. (2015) Diagnostic performances of CA125, HE-4, and ROMA index in ovarian cancer. Eur J Gynaecol Oncol 36(4): 457-462.

13. Drapkin R, Horsten VHH, Lin Y, Mok SC, Crum CP, et al. (2005) Human epididymis protein 4 (HE4) is a secreted glycoprotein that is overexpressed by serous and endometrioid ovarian carcinomas. Cancer Res 65(6): 2162-2169.

14. Moore RG, McMeekin DS, Brown AK, DiSilvestro P, Miller MC, et al. (2009) A novel multiple marker bioassay utilizing HE-4 and CA 125 for the prediction of ovarian cancer in patients with a pelvic mass. Gynecologic oncology 112(1): 40-46.

15. Hanyu C, Di Y, Zhu L, Hui Y, Minmin H, et al. (2018) Prognostic value of serum and tissue HE4 expression in ovarian cancer: a systematic review with meta-analysis of 90 studies. Expert Review of Molecular Diagnostics 18(4): 371-383.

16. Anastasi E, Marchei GG, Viggiani V, Gennarini G, Frati L, et al. (2010) HE4: a new potential early biomarker for the recurrence of ovarian cancer. Tumor Biol 31(2): 113-119. 
17. Angioli R, Capriglione S, Aloisi A, Guzzo F, Luvero D, et al. (2014) Can HE4 predict platinum response during first-line chemotherapy in ovarian cancer? Tumor Biol 35(7): 7009-7015.

18. Chudecka-Głaz A, Cymbaluk-Płoska A, Wężowska M, Menkiszak J (2018) Could HE4 level measurements during first-line chemotherapy predict response to treatment among ovarian cancer patients? PLoS ONE 13(3): e0194270.

19. Vallius T, Hynninen J, Auranen A, Carpén O, Matomäki J, et al. (2014) Serum HE4 and CA125 as predictors of response and outcome during neoadjuvant chemotherapy of advanced high-grade serous ovarian cancer. Tumor Biol 35(12): 12389-12395.

20. Siegel RL, Miller KD, Jemal A (2018) Cancer Statistics, 2018. Ca Cancer J Clin 68(1): 7-30.

21. Dong C, Liu P, Li C (2017) Value of HE4 combined with cancer Antigen 125 in the diagnosis of Endometrial Cancer. Pak J Med Sci 33(4): 10131017.

22. Presl J, Ovesna P, Novotny Z, Vlasak P, Bouda J, et al. (2017) Importance of preoperative knowledge of the Biomarker HE-4 in early- stage endometrial cancer regarding surgical treatment. AntiCancer Res 37(5): 2697-2702.

23. Fanfani F, Restaino S, Cicogna S, Petrillo M, Montico M, et al. (2017) Preoperative Serum Human Epididymis Protein 4 Levels in Early Stage Endometrial Cancer. Int J Gynecol Cancer 27(6): 1200-1205.

24. Moore RG, Brown AK, Miller MC, Badgwell D, Lu Z, et al. (2008) Utility of a novel serum tumor biomarker HE-4 in patients with endometrioid adenocarcinoma of the uterus. Gynecol Oncol 110(2): 196-201.

25. Knific T, Osredkar J, Smrkolj S, Tonin I, Vouk K, et al. (2017) Novel algorithm including CA-125, HE-4 and body mass index in the diagnosis of endometrial cancer. Gynecologic Oncology 147(1): 126-132.
26. Angioli R, Miranda A, Aloisi A, Montera R, Capriglione S, et al. (2014) A critical review on HE4 performance in endometrial cancer: where are we now? Tumor Biol 35(2): 881-887.

27. Dewan R, Dewan A, Hare S, Bhardwaj M, Mehrotra K, et al. (2017) Diagnostic Performance of Serum Human Epididymis Protein 4 in Endometrial Carcinoma: A Pilot Study. J Clin Diagn Res 11(7): XC01XC05.

28. Creasman W, Odicino F, Maisonneuve P, Quinn MA, Beller U, et al. (2006) Carsinoma of the corpus uteri: FIGO 26th Annual Report on the Results of Treatment in Gynecological Cancer. Int J Gyneacol Obstet 95(suppl 1): 105-143.

29. Howlader N, Noone AM, Krapcho M (2014) SEER Cancer statistics Review, 1975-2011. National Cancer Institute, USA.

30. Angioli R, Plotti F, Capriglione S, Scaletta G, Dugo N, et al. (2016) Preoperative local staging of endometrial cancer: the challenge of imaging techniques and serum biomarkers. Arch Gynecol Obstet 294(6): 1291-1298

31. Abbink K, Zusterzeel LMP, Geurts-Moespot AJ, Herwaarden EVA, Pijnenborg JMA, et al. (2018) HE4 is superior to CA125 in the detection of recurrent disease in high-risk endometrial cancer patients. Tumor Biology 40(2): 1-10.

32. Stiekem A, Lok C, Korse CM, Driel WJ, Noort V, et al. (2017) Serum HE4 is correlated to prognostic factors and survival in patients with endometrial cancer. irchows Arch 470(6): 655-664.

33. Bie Y, Zhang Z (2014) Diagnostic value of serum HE4 in endometrial cancer: a meta-analysis. World J Surg Oncol 12: 169.

\section{Your next submission with Juniper Publishers} will reach you the below assets

- Quality Editorial service

- Swift Peer Review

- Reprints availability

- E-prints Service

- Manuscript Podcast for convenient understanding

- Global attainment for your research

- Manuscript accessibility in different formats

( Pdf, E-pub, Full Text, Audio)

- Unceasing customer service

Track the below URL for one-step submission https://juniperpublishers.com/online-submission.php 